\title{
TRENDS AND ALTERNATIVES FOR PRODUCTION AND CONSUMPTION TOWARDS TO A NEW SYSTEM'S DYNAMIC
}

\author{
Minelle Enéas da Silva \\ Federal University of Rio Grande do Sul (UFRGS), Brazil \\ E-mail: minele.adm@gmail.com \\ Paola Schmitt Figueiró \\ Federal University of Rio Grande do Sul (UFRGS), Brazil \\ E-mail: paolaadm@gmail.com \\ Marcio Luis Miron Jappe \\ Federal University of Rio Grande do Sul (UFRGS), Brazil \\ E-mail: marcio.jappe@gmail.com \\ Luis Felipe Nascimento \\ Federal University of Rio Grande do Sul (UFRGS), Brazil \\ E-mail: nascimentolf@gmail.com \\ Submission: 06/08/2013 \\ Revision: 06/09/2013 \\ Accept: 16/09/2013
}

\section{Abstract}

The paper aims to study alternative forms of production and consumption and their convergence as a way to create a new system's dynamic. Firstly there is a theoretical discussion of the themes, then empirical evidence is discussed to make the case, and finally findings are discussed. The alternative forms of production and consumption, such as social business and collaborative consumption, are proven to be economically viable, and may satisfy also social and environmental concerns, in alignment with sustainable development concepts. This suggests they represent an opportunity to leverage a significant transformation in the whole system. The analysis performed can serve to the elaboration of public policies for development, by fomenting these alternative forms; and to incentivize entrepreneurs to create similar enterprises to create positive impact and simultaneously generate profits. The empirical evidence collected is restricted. For further and more conclusive findings the range of the examples researched must be increased. 
Keywords: Business Models; Social Business; Collaborative Consumption; Capitalism Crisis.

\section{INTRODUCTION}

The capitalism, just as it has happened before, is going through a crisis, due to its incapacity of selling the production and generating profits, indicating it cannot be sustained over time (ONARAN, 2010; VANDEPITTE, 2011). Is the idea of capital accumulation being suffocated, giving space for a new vision? Foster and Magdoff (2011) consider that "replacing capitalism by a new economy, oriented towards sustainable human development, ecological plenitude, and the nurturing of an authentic human community". Would this be the alternative?

Global society lives in contradiction. On one hand the need to sustain the capitalism practices is discussed, on the other an alternative form of dealing with the available resources. In a critical perspective, Lélé (1991) indicates there are inherent contradictions in the sustainability debate, since it happens fully within capitalism ideas. According to the author, the debates do not take into consideration the literal ecological and social concept inherent to the theme's ideal. This becomes clearer as the development model of capitalism incorporates the sustainable development debate, creating its own coping mechanisms, such as the carbon markets. How to legitimate the debate?

Questioning capitalism is an interesting tactic for the construction of a different social dynamic, but would sustainability be the best option? Leveraging on that, and being directly involved in a reflexive field, our discussion argument is built as this: is a restructuring movement with rise of new practices and behaviors possible, or it is necessary a full change in the system? Driven by this question, the discussion will be carried on without extremisms, bringing to light the approach the researchers believe to be the most adequate to deal with current contradictions.

Overall, most of the proposals presented to overcome the current crisis remain the same: increasing consumption with more abundant credit will fuel growth. However, the conditions changed. Part of the production has moved to developing countries, there is more environmental consciousness, corporate social responsibility is increasing, there are movements questioning consumerism, and the new generation blossoms with new behavior patterns. New forms of consumption arose, 
INDEPENDENT JOURNAL OF MANAGEMENT \& PRODUCTION (IJM\&P)

http://www.ijmp.jor.br

v. 5 , n. 1 , October - January 2014.

ISSN: 2236-269X

DOI: 10.14807/ijmp.v5i1.117

trying to satisfy needs without buying. Global society is transitioning to a new dynamic.

Two perspectives are possible. One observing how production happens, the other how the production is "consumed". According to Lipovetsky (2007), there is a paradoxical happiness in a daily life in hyper-consumption, as the homo consumericus does not take into consideration the consequences of his unsustainable practices. There are new concerns to change the individual consumption focus towards a broader and more conscious vision (MICHAELIS, 2000). For Jackson (2005, p.03) "changing our own behaviour is difficult; certainly more than we wish". This will lead to a different dynamic, more collective than historically observed.

The increasing demand for more corporate responsibility on its impact on society goes on this direction. Clarkson's (1995) speaks about the need to look for a more positive corporate social performance, involving the development of relations where there is a more pro-active social behavior. Therefore, there will be an adaption to a new dynamic or a renewal of the existing one. One approach to this is to maximize the contextual role of the productive process. Why not increasing the focus on a services-based economy instead of depleting natural resources? Why not offering goods for those who really need them, instead of allocating resources to market for the richer?

This notion of change indicates that consumers are able, in the midst of a conjunction of social interactions, to take a more collective approach, where rather than consumers, they are citizens (JACKSON, 2007; SEYFANG, 2006; SPAARGAREN, OOSTERVEER, 2010), Reclaiming citizenship is an interesting. The rise of new forms of consumption is not constrained to individual actions of buying goods to satisfy needs, but includes collaborative consumption, focusing on: products as services; redistribution markets; and collaborative life-styles (BOTSMAN; ROGERS, 2011).

This paper aims to identify how different forms of production and consumption can drive the system into a new dynamic. This perspective is justified by considering transformation as the most suitable option to build a new system's dynamic, taking into consideration aspects such as the collective, sharing and collaboration. These should converge in such a way that it is possible to attain the transformation 
INDEPENDENT JOURNAL OF MANAGEMENT \& PRODUCTION (IJM\&P)

objectives. For better understanding, this paper has five sections after the introduction. Firstly, a vision of the current capitalism crisis is conveyed. Then new forms of production and consumption are discussed, followed by examples where a new dynamic is being nurtured and tested. Finally, a brief discussion on the overall findings and academic contribution finishes this paper.

\section{THE CAPITALISM CRISIS: EVIDENCES OR RECONSTRUCTIONS?}

All along its existence, capitalism has presented variations (crises) which are part of a production system, and that many times make it stronger. However, since 2007, the economy is facing an acute systemic crisis, compared to the Great Depression (ONARAN, 2010). According to this author, despite of being initiated in the USA, the impact of the crisis spread through several other countries, especially in Europe. This emphasizes the influence capitalism has on society, and shows the economic growth rates of the central countries are flattening (FOSTER; MAGDOFF, 2011).

According to Vandepitte (2011), the global market (consumer goods, services and finances) has been subordinated, manipulated and structured in favor of the leading capitalist countries. However, as indicated by Foster and Magdoff (2011), the advanced capitalist economies are captured in stagnation, which results from the processes of industrial maturity and monopolist accumulation. Onaran (2010) shows that the difference between the current and all other economy crises is that this has a global impact and was originated in the central capitalist countries. Therefore, this crisis has a stronger global impact, changing the way it must be looked into.

Although there is great understanding about the conditions of the crisis, DeCock, Baker and Volkmann (2011) indicate that both the financial sector and the big companies make a big effort to deny there is a capitalism crisis. But every time capitalists start talking about capitalism, it is in trouble (EAGLETON, 2011). This decadence is not totally unexpected, since according to Mandel (2001) revolutions on production means happen "periodically", meaning there is no production system that up until now was able to survive indefinitely. This fact was noted when Eagleton (1997) mentions capitalism overestimated its production, paving the way to its own denial. 
INDEPENDENT JOURNAL OF MANAGEMENT \& PRODUCTION (IJM\&P)

On his critique to capitalism, Marx indicates that its consolidation happened through a revolution, in this case the industrial revolution. However, he argues that by the increase of individual consciousness, the emergence of a new vision is possible. According to Eagleton (2011), Marx thought that the emancipation of the individuals could happen in the context of the society. And these consciousness and emancipation could serve as the stepping-stones for a revolution to be started.

As an alternative to the crisis, and aligned with the perspective of change and restructuring of the system, the discussions about sustainable development emerge. The basic idea relates to the change in behavior of different players in society so that there is harmony among social, environmental and economic aspects (World Commission on Environment and Development [WCED], 1987). According to Foladori (2005), it is possible to direct the individualistic characteristics that capitalism emulates towards a more collective vision. However, there is a lot of debate around the possibility of adequacy between ideas such as collective orientation and harmony with the capitalist thinking.

According to Prothero and Fitchett (2000, p.48), "any definition that uses contemporary understanding of the human nature and needs to define a green society cannot be considered different of the capitalist production system, since these terms emerged as part of the cultural conditions of capitalism itself'. However, for the researchers discussing sustainability as essential for a change in social values, this is an insult. The idea of sustainability is not to bring a new profile to the capitalist decline (Smith, 2007), but to search for the emergence of a new vision.

This new vision might be compelling, but there is still significant action that goes against its principles. This is the case for the carbon markets. As presented by Böhm, Misoczky and Moog (2012), many still see the carbon markets as a viable tool to deal with climate change, not by changing the basic perspective, but by considering it a way of reinventing and 'greening' the capitalism. According to these authors, there are evidences showing that the recent 'green' practices financed by the carbon markets are unsustainable and can be considered a capitalist pathology. Again new ways of spreading capitalism are established (SMITH, 2007).

Contrary to what Onaran (2010) indicates about sustainability (the need for zero or slow growth in developed countries), what is going on is the need for restructuring in production system and in consumption relations, so that a better 
INDEPENDENT JOURNAL OF MANAGEMENT \& PRODUCTION (IJM\&P)

articulation in society happens. This idea is presented by Hopwood, Mellor and O'Brien (2005) as they indicate different approaches for sustainability, taking into consideration a transition where the status quo should be fought, where a more significant transformation should happen, using new lenses and new consciousness.

In this sense, a vision of a societal long transition towards a new perspective is considered (ONARAN, 2010), with the argument that the increase in consciousness is the ignition point for the whole change. This is aligned to what Marx (1980) indicated about the need of individuals to evolver through their social relations, stimulating an alternative thinking. As he suggested, the global population should not simply leave behind everything it has experienced, but focus on a new way of seeing the world. From this perspective, it is understood that the increase in consciousness and the alignment to a more collective view emulate the articulation of a new dynamic, about which more aspects will be discussed along the article.

\section{A DIFFERENT PERSPECTIVE ON PRODUCTION SYSTEMS}

For Maharajh (2012), the crises facing the planet are a result of production systems, consumption patterns, and environmental degradation. He thinks a green economy should be built upon the capitalist crisis. This debate resembles to the debate developed so far on bringing a transformative perspective, in which the focus is not simply pointing out that there is a crisis, but trying to figure out alternatives to it. On the same direction, Berg and Hukkinen (2011) analyzed the studies about the restructuring of the capitalist economy focused on making it more environmental friendly. They emphasize the influence of both the United Nations Environment Program (UNEP) and the Organization for Economic Co-operation and Development (OECD) on the promotion of "green growth" and "green economy" concepts.

There are different understandings about what is a green economy, and about what are the steps towards sustainability. But, in a certain way, everyone discusses the need of different forms of production and consumption. This suggests a continuum can be created to change the status quo to a more sustainable reality. According to Thorpe (2009), establishing Sustainability depends on developing Clean

Process and Clean Products, and then reach Closed Loop Systems and a BioSociety, as shown in Figure 1. 
INDEPENDENT JOURNAL OF MANAGEMENT \& PRODUCTION (IJM\&P)

http://www.ijmp.jor.br

v. 5, n. 1, October - January 2014.

ISSN: 2236-269X

DOI: 10.14807/ijmp.v5i1.117

Each step has its own objectives. "Clean Process" is focused on pollution prevention, rethinking manufacturing, toxic use reduction, aiming at safe manufacturing and production systems. On "Clean Products", the focus is on product policy, life cycle thinking, product labeling, green procurement and ecotax, aiming at green products from cradle to grave. On "Closed Loop Systems", the focus is on extend producer responsibility, industrial ecology and zero waste, aiming at material reuse and recycling, just like nature does. Finally, on "BioSociety", the focus is on the natural step, ecological engineering, bio-based materials, detoxifying our materials, dematerializing our economy, emerging technologies, aiming at human societies and the world's ecosystems that maintain stability and diversity (THORPE, 2009).

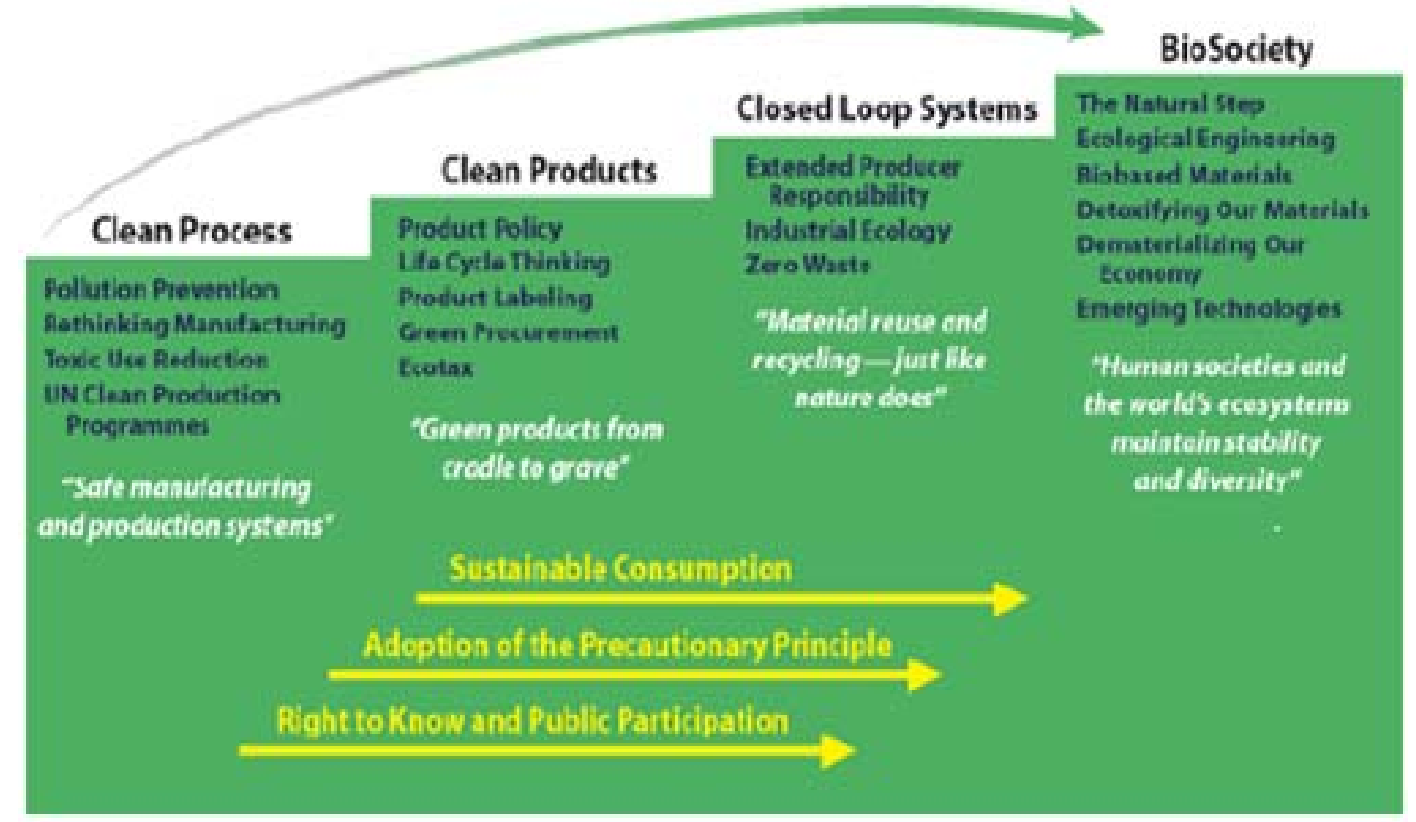

FIGURE 1 - Steps to Sustainability

Source: Clean Production Action (Thorpe, 2009)

The tools, methodologies, and programs used in each step are related to forms of production and consumption. The UN Cleaner Production Programs were developed by United Nations Industrial Development Organization (UNIDO) and UNEP, to spread cleaner production to developing countries. According to UNIDO (2002), "cleaner Production is a strategy that protects the environment, the consumer and the worker while improving the industrial efficiency, profitability and competitiveness of enterprises". In the 1990's the focus of organizations such as those was to reduce the impact of production on the environment. In the 2000's, production started being associated to consumption, as the two sides of same issue. 
INDEPENDENT JOURNAL OF MANAGEMENT \& PRODUCTION (IJM\&P)

Researchers and official documents started replacing "cleaner production" with "sustainable production and consumption".

The authors of the "Natural Capitalism" (LOVINS; LOVINS; HAWKEN, 1999) show how to simultaneously supply the consumption demand, and to reduce production. According to the authors, the "next industrial revolution" depends on the espousal of four strategies: the conservation of resources through more effective manufacturing processes; the reuse of materials as found in natural systems; a change in values from quantity to quality; and investing in natural capital, restoring/sustaining natural resources. One of the ideas is to design business models that deliver services instead of products, creating an economy of services and flow (HAWKEN; LOVINS; LOVINS, 1999).

The services industry can supply consumption demand in several ways that do not demand the acquisition of new products, such as printing services in companies, for example. Instead of buying printers, ink, and paper, companies buy a number of printings, or rent the printers. Examples of renting services are abundant, both in terms of offers (computers, cars, and other machinery) and in contract forms (leasing, pay per use, pay per hour). This service economy can cause less environmental impact than business as usual, since the incentive systems are for durability of products to increase the time length of the revenue flow, instead of their quickly disposal for new products to be manufactured and sold. It can generate more jobs locally, since the "production" and deliver of the service cannot be as detached from the client as it might happen with the manufacturing of products to be sold.

Production and consumption also converge when social problems are the focus. In the 2000's, methodologies such as the Design Thinking spread around. The term was crafted by David Kelley, founder of IDEO (LEAVY, 2012), an international consulting firm that helps organizations to innovate and to overcome their challenges (IDEO, 2012). The increasing usage of this methodology is due to its focus on the human being, and by the fact it sees multidisciplinary, collaboration, and translation of thoughts and processes as paths that lead to innovative business solutions (VIANNA et al., 2012).

The solutions can be applied both on the poorest regions of the planet, and on the most developed nations. Challenges demand innovative alternatives, as a result of the interaction of professionals from different areas, who believe in collaboration 
INDEPENDENT JOURNAL OF MANAGEMENT \& PRODUCTION (IJM\&P)

as a way of generating creative solutions. How to feed and educate the more than three billion people living on less than two dollars a day? How to make sure megacities in developed countries are sustainable and safe for their inhabitants? New forms of production are essential to supply the consumption demands in a sustainable manner, or in other words, in a way that is economically viable, socially fair, and friendly to the environment. More than new forms of production, new business models are needed.

\section{A NEW MODEL: BUSINESS IN (REAL) SERVICE OF SOCIETY}

As previously stated, despite of general advancement in terms of global life quality, as shown with the increase in global life expectancy over the decades (WORLD BANK, 2012), part of the global population suffers from 'solvable' problems: 2.6 billion have no access to basic sanitation and survive on less than two dollars a day, 1.6 billion have no access to electricity, and 0.9 billion have no access to drinking water (WHO, 2010; UNICEF, 2010; WORLD BANK, 2012; UNDP, 2008). The evidences show challenges are getting bigger and more complex, raising questions about the role of governments, private sector, and non-profits. New models are needed, combining the private sector's efficiency and the third sector's purposeorientation, without the blind focus on profit maximization of companies and the lack of financial viability in the third sector.

This context gave birth to the idea of organizations solving social challenges in a financially viable manner, through market mechanisms (offering products and services respecting the laws of supply and demand), the "Social Business". They differentiate from traditional business, corporate social responsibility, specific offerings to the base of the pyramid, and non-profits. They profitably market products and services that contribute for the increase of quality of life of the poorest, meaning there is no need of fundraising to sustain the organization's activities (ARTEMISIA, 2011). The idea sounds applicable to most developing countries. Lets take Brazil as an example. Firstly, there are social challenges in habitation, health and education, and $78 \%$ of the population is middle class or down in the economic pyramid (IBGE, 2011; CETELEM IPSOS, 2011). Secondly, Brazil is considered a highly entrepreneurial country (GLOBAL ENTREPRENEURSHIP MONITOR, 2011). And, finally, it is one of the biggest economies in the world, with favorable conditions for 
INDEPENDENT JOURNAL OF MANAGEMENT \& PRODUCTION (IJM\&P)

new enterprises, and financial resources readily available for the development of these businesses.

One important moment for the popularization of the term "social business" globally was the Nobel Prize ceremony in 2006. About 30 years after founding Grameen Bank in Bangladesh, and successfully lending more than six billion dollars in microcredit to more than seven million people ( $97 \%$ of them women, with only $1 \%$ default rate), leveraging $58 \%$ out of extreme poverty, Muhammad Yunus was laureate with the Nobel Peace Prize that year. In his speech, he mentioned the positive impact of Grameen Bank and other Grameen ventures, such as a joint venture with Danone to market low cost nutritious yogurt for the poor in Bangladesh, and a low cost eye care clinic in India. He presented to the world the concept of social business, as those where the bottom-line is social, and the profit is the mean to sustain and increase the positive impact. He arguments that any social problem in the world could be tackled by a social business, and goes beyond, saying that social business will be developed both by companies looking for more efficiency on their corporate social responsibility initiatives, and by leaders in non-profits looking towards focusing more in creating impact rather than merely fundraising.

The Grameen Group work in several examples of social businesses, such as Grameen DANONE. Besides the previously mentioned, it is noteworthy the fact that the whole development of the organization happened in a close partnership with the local community, and that there were several other innovations: the customization of the product and of its distribution to local needs, such as more resistance to heat, and distributing the product through networks of women whom are GrameenBank's clients; and production units which are 20 times smaller than the smallest Danone's traditional one. Other examples are the Grameen Phone for the mobile phone market, and the Grameen Shakti in the energy production and distribution (YUNUS, 2010).

The empirical observation of these organizations shows some strategies that seem to be working well. The first is to connect impoverished people to existing markets, because simply accessing the same products and services as the richer help them to improve their own situation, overcoming that lack of access that makes the poor pay more for goods and services. Microcredit banks and fair trade organizations are good examples. Another strategy is to leverage on the existing 
INDEPENDENT JOURNAL OF MANAGEMENT \& PRODUCTION (IJM\&P)

networks in the local communities, supporting the formation of multi-sector partnerships. Instead of pushing top-down, bottom-up solutions are 'pulled-out', customized to local needs, generating more local buy-in and engagement, and cheaper.

One indication these business models are expanding is the fact that besides Yunus and his definition, there several other individuals and organizations studying and giving them names, such as "business with the bottom of the pyramid", "business with the base of the pyramid 2.0", "shared value enterprises", and "inclusive business". Also, other organizations are using the term "social business" in a slightly different fashion from Yunus, such as Artemisia and Ashoka (ARTEMISIA, 2011). These possibilities suggest that a significant change in the system can be generated, since these new forms of production articulated in different business models are dynamic, and create new social relations and stimulate news forms of consumption. Some of them will be articulated in the following sections.

\section{THE COLLABORATION AND INNOVATIVE FORMS OF CONSUMPTION}

There are some aspects among all presented so far that indicate that not only change in production will drive change in consumption, but also that change in consumption will drive change in production as well. However, according to Michaelis (2000), there are forces that interfere in an active behavior: intrinsic human tendency towards an escalation of desire - consumerism; growth of consumption may be related to specific technological and institutional developments; use of material consumption to meet social needs; the competitive market system; and expectation that the material quality of life should improve continually. If these aspects are satisfied without worrying about their impacts, the potential for change and the formation of a new social vision is reduced.

But, on the other hand, change still has its possibilities, since several aspects influence the transformational process. Let's take the example of Information and Communication Technologies (ICTs). Statistics indicate that the number of internet users increase in 112 million people in 2011 alone, meaning 15\% more increase compared to 2010. Also, there are the increasing usage of mobile technologies, as shown in the $117 \%$ increase in smart phones sales in Latin America in 2011 compared to 2010 (ABRADI, 2012). As a result, the individual need of belonging to a social group is more and more being centralized in virtual platforms of communication 
INDEPENDENT JOURNAL OF MANAGEMENT \& PRODUCTION (IJM\&P)

(MONT, 2004), allowing exchange and sharing, as much production and creation of collective innovations (KOZINETS; HEMETSBERGER; SCHAU, 2008).

Taking into consideration this vision, Friedman (2005) affirms that competition and collaboration at global scale, among individuals and companies, are now cheaper, easier, less conflictive, more productive, and reaching an ever increasing number $f$ people. Global society lives in an era where "technology will literally transform the business world, life, and society in all aspects" (FRIEDMAN, 2005, p.231). According to Friedman (2005), in the 2000's a global playing field was created and, articulated through the web, made different forms of collaboration viable, meaning the sharing of knowledge and work at global scale. According to Belk (2007), sharing here can be understood as the act or process of distribution of what is ours for others to use, and/or the act or process of receiving/taking something that belongs to others for our own use. So, for Cheshire and Antin (2008), it become significantly easier to share texts, songs, movies, software's, and several other products in digital format. Besides that, there are several on-line communities flourishing, and a trend towards collective production and innovation (KOZINETS et al., 2008).

This way, the advancement and dissemination of the ICTs made possible new forms of sharing, and the ascension of platforms for collective practices that allow interaction, free access to information, knowledge exchange, creation and collaboration. On an organizational environment, this practices indicate new business models, new ways of conducting decision making processes, product development, collective learning, and so on and forth. It can be said that innovation in several leading companies are increasingly a result of horizontal collaboration, among different departments and teams spread all over the globe (FRIEDMAN, 2005). This author also points out that many companies started seeing their employees as a great conglomerate of individual specialists that can be horizontally united in collaborative teams, in accordance to the specific requisites of each project (FRIEDMAN, 2005).

For collaboration tools to be developed, it is necessary that individuals generate collective action. Besides that, trust is an important facilitator of collective practices (BOTSMAN; ROGERS, 2011), influenced by the level of identification between the individuals (KRAMER, 1999). For a better understanding of the 
INDEPENDENT JOURNAL OF MANAGEMENT \& PRODUCTION (IJM\&P)

possibilities of collective practices, Botsman and Rogers (2011) mention three systems embed in the concept of sharing: services of products system; redistribution markets; and collaborative life styles.

The 'services of products systems' involve a form of consumption where there is a payment for the usage of a product without the need to acquire it (BOTSMAN; ROGERS, 2011). As examples, they mention the rent of fashion accessories, tools, books, and car and bike sharing systems. The 'redistribution markets' are associated to exchanges and donations of different items, referring to the ownership transfer. Finally, in the 'collaborative life styles', individuals are inclined to sharing and exchanging intangible assets such as time, space, skills, money, and other resources (BOTSMAN; ROGERS, 2011).

This consumption system includes different movements associated with collaboration: crowdsourcing: co-creation tools leveraged by on-line collective collaboration; crowd funding: collective financing leveraging on networks of individuals and/or organizations that invest in creative projects (collaborative engagement); crowd learning: collaborative learning tools that enable the exchange between those who want to teach something, and those who want to learn it; couch surfing: people share spaces in their home to host people travelling; and co-working: collective working spaces (ORDANINI; MICELI; PIZZETTI, 2011; BRABHAM, 2008; LAUTERBACH, 2009; SWEET; MOEN, 2004).

According to Botsman and Rogers (2011), users of collaborative systems are not only looking for accessing products and services at lower costs. They are also motivated to engage in such initiatives because of the people gathering, the experiences, and the fact they become more socially conscious and sustainable. Collaborative systems can, in fact, be more friendly to the environment by increasing usage efficiency, reducing waste, incentivizing better products, and by absorbing the exceeding of production and consumption (BOTSMAN; ROGERS, 2011).

However, there are obstacles, such as the hesitation to use the infrastructure available (FRIEDMAN, 2005). Belk (2007) adds as impediments the feelings of possession and attachment, the materialism, and the perception that the resources are scarce and that sharing can lead to loss, as there is not ownership of the things. According to Mont (2004), the number and quality of possessions accumulated is also perceived as a way of measuring success in life, as a sign of power, social 
INDEPENDENT JOURNAL OF MANAGEMENT \& PRODUCTION (IJM\&P)

status, and feeling of happiness. Characteristics that are peculiar to the each local culture, but that are being transposed to a new system dynamic. A practical assessment of these possibilities of change is performed in the following section.

\section{A NEW DYNAMIC FOR THE SYSTEM: A PRACTICAL ASSESSMENT}

Understanding that new forms of production and consumption can arise for a systemic transformation, it becomes clear that structural conditions should exist to allow this change to happen. ICTs are key to that, since they facilitate social relations to happen in more collective, shared, and collaborative manner. The available infrastructure (the internet) "should foment the mass sharing of practices and knowledge", and that the economy will incentivize sharing as much sharing will incentivize the economy (FRIEDMAN, 2005, p.218). This recursive thinking contributes to the understanding that if an isolated action does not enable objectives to be reached, it is necessary to follow different paths towards the change that people aim for.

The authors understand that it does not matter the origin of change, either be it on the production or the consumption. What matters the most is the concern about social and environmental impacts of both our actions and discussions. Hopwood, Mellor and O'Brien (2005) make it clear the ambiguous character of the existing debates and documents, but still suggest that it is from this transformation that a new social dynamic can arise.

This notion explicit how the context is becoming more friendly to change towards a more collective and collaborative approach. Let's take the Brazilian scenario as an example. A research run with 1700 young people between 18 to 24 years old, the first generation born and raised on the Internet and social networks age, point out that they are more conscious and collective oriented: $77 \%$ agree that their well-being depends on their local society's well-being, and $74 \%$ feel obligated to do something positive for the collective in their daily routines (BOX 1824, 2011).

The diffusion of concepts and life styles that translate economic, social, and environmental concerns into practice leveraging on the existing technology explicit the possibilities of change. This process can result in a transformation in production and consumption patterns, and therefore in a systemic change. The collaborative consumption is neither a niche trend nor an eventual reaction to recession, but new 
socioeconomic waves that will change companies translate their value proposition into the customer needs satisfaction (BOTSMAN; ROGERS, 2011). Below some examples which translate these concepts into reality are presented, proving this trend is something real and alive.

TABLE 1 - Examples of collaborative practices - a different form of consumption

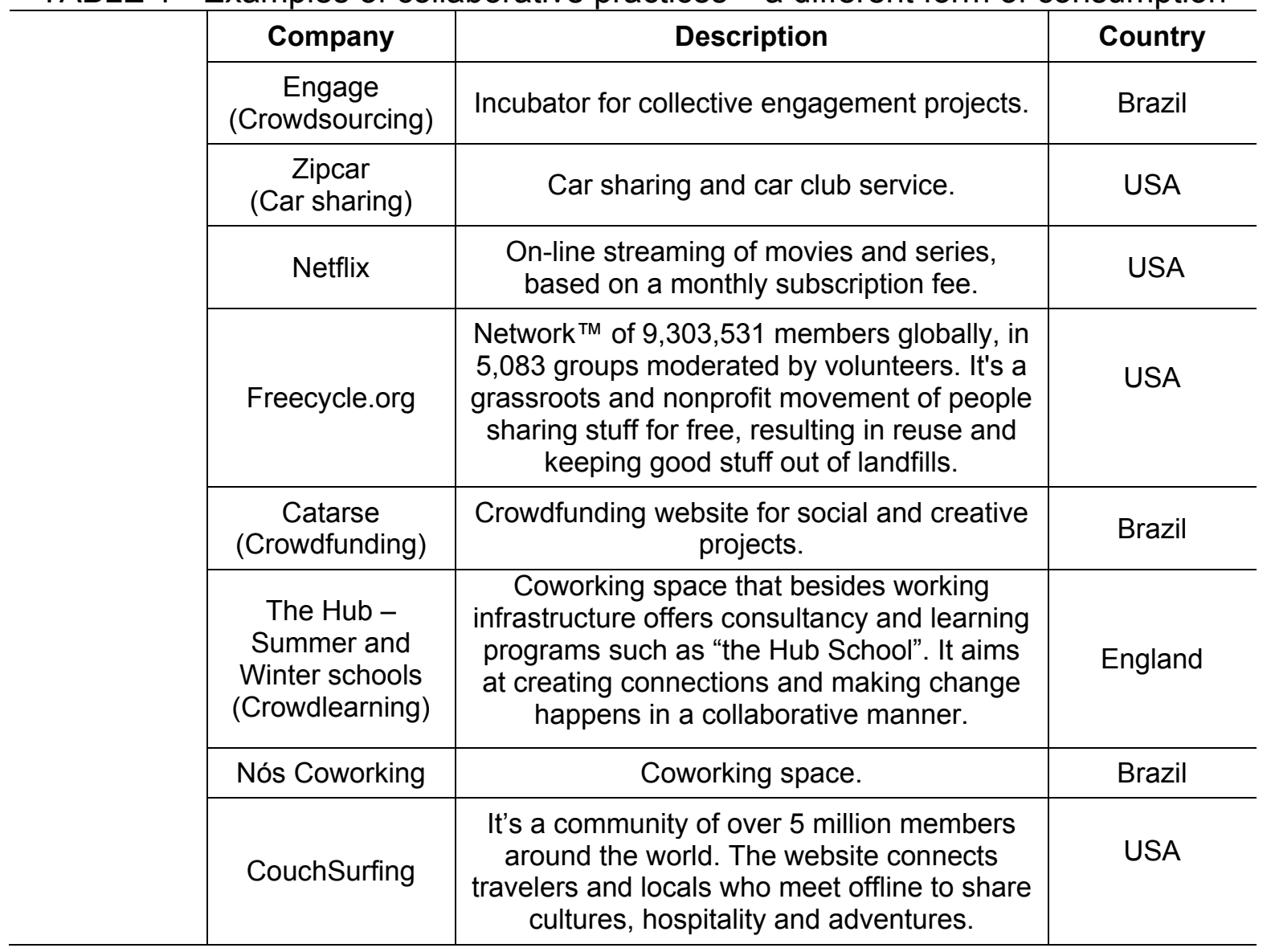

The collaborative dynamic of the companies mentioned above explicit a new global scenario, where solving social and satisfying social demands makes business sense. Crowd funding, for example, solves the fundraising challenge of innovative business and creative initiatives that otherwise would not call the attention of traditional investors. Even more focused on overcoming specific social challenges are the previously mentioned social business. Table 2 shows some examples around the globe. 
INDEPENDENT JOURNAL OF MANAGEMENT \& PRODUCTION (IJM\&P)

http://www.ijmp.jor.br

v. 5, n. 1, October - January 2014.

ISSN: 2236-269X

DOI: 10.14807/ijmp.v5i1.117

TABLE 2 - Examples of Social Business - a different form of production

\begin{tabular}{|c|c|c|}
\hline Organization & Description & Country \\
\hline www.bancoperola.org.br & $\begin{array}{l}\text { Microcredit bank that is focused on lending to } \\
\text { group of young people between the ages of } 18 \\
\text { and } 35 .\end{array}$ & Brazil \\
\hline www.selco-india.com & $\begin{array}{l}\text { Offers low cost solar energy solutions in rural } \\
\text { areas in India. }\end{array}$ & India \\
\hline www.lifespring.in & $\begin{array}{c}\text { Hospitals with } 20 \text { to } 25 \text { beds, specialized in } \\
\text { maternal care. }\end{array}$ & India \\
\hline www.aravind.org & $\begin{array}{l}\text { Hospital focused on treating preventable } \\
\text { blindness with } 300,000 \text { surgeries a year, } 2 / 3 \text { of } \\
\text { them free of charge. }\end{array}$ & India \\
\hline www.cdilan.com.br & $\begin{array}{l}\text { Through the cooperation with hundreds of } \\
\text { thousands of lan houses present in poor } \\
\text { communities, using them as a platform to } \\
\text { providing financial and educational services. }\end{array}$ & Brazil \\
\hline www.solidarium.com.br & $\begin{array}{c}\text { Fair trade company that connect local } \\
\text { producers with big retailers for } \\
\text { commercialization }\end{array}$ & Brazil \\
\hline
\end{tabular}

It is clear these different forms of production and consumption positively impact the lives of many around the globe, and that these benefits could be extended to an ever bigger number of people, creating waves of change into the system. An interesting aspect is that this could happen as a result of pro-active actions, and not only as a response to a crisis situation. In a consistent manner, it could be said that the adoption of these different forms of production and consumption recall the origins of capitalism, when corporations where formed to solve social problems and to satisfy social needs, such as building a bridge or opening up a road for a community to communicate with others. Should this be a reflection of the past or could it be what global society wants for the future? Will alternative forms of production and consumption be restricting to niches, or will they reach global scale?

\section{FINAL REMARKS}

For society as a whole to reach collectiveness level where there is a search to satisfy the needs of those who produce and consume, it is increasingly clear that it is crucial to rethink and restructure the practices and patterns that are currently in place. The discussion presented in this paper suggests that there are possibilities to change patterns, to adopt new forms of production and consumption, and, therefore, to create the systemic change needed. A more active approach is needed for the creation of this alternative reality. 
INDEPENDENT JOURNAL OF MANAGEMENT \& PRODUCTION (IJM\&P)

The forms of production presented are economically viable, have a less significant environmental impact, and tackle social challenges and concerns. Their business models differ from traditional ones, but function in a similar fashion in terms of efficiency, and profit generation. Capitalism has inherent contradictions and crises are part of its operating system. Some of these crises are long lasting, some are short, but in all cases they are part of its development. Contextual conditions of each period of time lead to different ways out of each crisis, which sometimes means merely escaping rather than creating long lasting real change. Currently, the context involves the increasing in environmental consciousness, which reflects in the adoption of alternative forms of production and consumption.

Questioning if new practices are enough or a more fundamental systemic change is needed is necessary. The authors understand the experiences and cases presented in this paper are still insipient, but are relevant and can be easily shared, and replicable if customized to new realities, increasing their impact. Connecting profits and positive social impact is a dream scenario for many, and as of it was seen in the examples presented, it is more possible that previously imagined. It is worth noting that the ICTs will play a fundamental role in any change to happen in the coming years/decades, both in changing production, and in changing consumption. The possibilities are immense.

The realization that it is possible to innovate and to reach profitably goals in consonance with social and environmental concerns is important. Collaboration can be a catalyst for change, and methods such as the Design Thinking, amongst others, can make a big difference in organizational performance. In this paper the authors chose to have a theoretical discussion, and then support it with some empirical evidence. Although it makes a more compelling case, it is also one of the biggest limitations of the study, since the cases are neither mutually exclusive nor collective exhaustive. However, trying to articulate the dialogue within topics which usually are not connected is a great contribution for the development of public policies towards more sustainable forms of production and consumption, being as well a good incentive for new entrepreneurs to start similar ventures, in a more collective, collaborative, open-sourced manner. 


\section{REFERENCES}

ABRADI. Brazilian Association of Digital Agencies. (2012) Internet no Brasil cresceu $16 \%$ em um ano. Available: http://www.abradi.com.br/noticias/ibopenielsen-online-internet-no-brasil-cresceu-16-em-um-ano/ Access: 22/11/ 2012.

Artemisia. (2011) Entenda o conceito [Understand the concept]. Available: http://www.artemisia.org.br/entenda_o_conceito.php Access: 21/04/2012.

BELK, R. (2007) Why Not Share Rather Than Own? Paper presented at the Annals of the American Academy of Political and Social Science.

BERG, A.; HUKKINEN, J. I. (2011) Beyond effectiveness: The uses of Finland's national programme to promote sustainable consumption and production, Journal of Cleaner Production, v.19, n.16, p.1788-1797.

BÖHM, S.; MISOCZKY, M. C.; MOOG, S. (2012) Greening Capitalism? A Marxist Critique of Carbon Markets, Organization Studies, v. 33, n.11.

BOTSMAN, R.; ROGERS, R. (2011) O que é meu é seu: como o consumo colaborativo vai mudar o mundo. Porto Alegre: Bookman.

BOX 1824. (2011) Projeto Sonho Brasileiro [Brazilian Dream Project]. Available: http://osonhobrasileiro.com.br/ Access: 04/01/ 2013.

BRABHAM, D. C. (2008) Crowdsourcing as a model for problem solving: An Introduction and Cases, Convergence: The International Journal of Research into New Media Technologies, 14.

CETELEM IPSOS. (2011). O observador - Brasil 2011. Available: http://www.cetelem.com.br/portal/elementos/pdf/pdf_observador2011_BR.zip Access: 18/04/ 2012.

CHESHIRE, C.; ANTIN, J. (2008) The Social Psychological Effects of Feedback on the Production of Internet Information Pools, Journal of Computer-Mediated Communication, v. 13, p. 705-727.

CLARKSON, M. B. E. (1995) A stakeholder framework for analyzing and evaluating corporate social performance, Academy of Management Review, v. 20, n. 1, p. 92117.

Decock, C.; BAKER, M.; VOLKMANN, C. (2011) Financial phantasmagoria: corporate image-work in times of crisis, Organization, v. 18, n. 2, p. 153-172.

EAGLETON, T. (1997) Marx. São Paulo: Editora UNESP.

EAGLETON, T. (2011) In Praise of Marx. Available: http://chronicle.com/article/InPraise-of-Marx/127027/ Access: 25/05/2012.

FOLADORI, G. (2005) Por uma sustentabilidad alternativa. Uruguai: Colección Cabichui.

FOSTER, J. B.; MAGDOFF, F. (2011) The great financial crisis - three years on. Monthly Review. Available: http://monthlyreview.org/2010/10/01/the-great-financialcrisis-three-years-on Access: 25/05/2012.

FRIEDMAN, T. (2005) O Mundo é Plano: Uma breve história do século XXI. Rio de Janeiro: Objetiva. 
Global Entrepreneurship Monitor. (2011) Global Report. Available: http://www.gemconsortium.org/docs/2409/gem-2011-global-report Access: 28/05/2012.

HAWKEN, P.; LOVINS, A. B.; LOVINS, L. H. (1999) Natural Capitalism: Creating the Next Industrial Revolution. Little, Brown \& Company.

HOPWOOD, B.; MELLOR, M.; O'BRIEN, G. (2005) Sustainable Development: Mapping Different Approaches, Sustainable Development, v.13.

IDEO. (2012) About IDEO. Available: http://www.ideo.com/about. Access: 18/01/ 2013.

IBGE. Brazilian Institute of Geography and Statistics. (2011) Brazilian Population. Available: http://www.ibge.gov.br/home/ Access: 19/01/ 2013.

JACKSON, T. (2005) Motivating Sustainable Consumption: a review of evidence on consumer behaviour and behavioural change. Sustainable Development Research Network. Center for Environmental Strategy, University of Surrey.

JACKSON, T. (2007) Sustainable Consumption. In: Atkinson, G.; Dietz, S.; Neumayer, E. (Ed.). Handbook of Sustainable Development. Edward Elgar Publishing.

KOZINETS, R. V.; HEMETSBERGER, A.; SCHAU, H. J. (2008) The Wisdom of Consumer Crowds: Collective Innovation in the Age of Networked Marketing, Journal of Macromarketing, v. 28, n. 4, p. 339-354.

KRAMER, R. M. (1999) Trust and distrust in organizations: emerging perspectives, enduring questions. Annual Review Psychology, v. 50, p. 569-598.

LAUTERBACH, D.; TRUONG, H.; SHAH, T.; ADAMIC, L. (2009) Surfing a web of trust: Reputation and Reciprocity on CouchSurfing.com. Paper presented at the annals of the International Conference on Computational Science and Engineering, IEEE.

LEAVY, B. (2012) Collaborative innovation as the new imperative - design thinking, value co-creation and the power of "pull", Strategy \& Leadership, v. 40, n. 2, p. 2534.

LÉLÉ, S. M. (1991) Sustainable Development: A Critical Review, World Development, v. 19, n. 6, p. 607-621.

LIPOVETSKY, G. (2007) A felicidade paradoxal: ensaio sobre a sociedade de hiperconsumo. São Paulo: Companhia das Letras.

LOVINS, A. B.; LOVINS, L. H.; HAWKEN, P. (1999) A Road Map for Natural

Capitalism, Harvard Business Review, p. 145-158.

MAHARAJH, R. (2012) Rio+20: Peoples' Sustainability Treaties \& the Manifesto. Available: http://www.ramapo.edu/masters-sustainability/docs/after-rio20/3/Maharajh-Capitalist-Constraints-110812.pdf Access: 23/11/ 2012.

MANDEL, E. (2001) O lugar do marxismo na história. São Paulo: Xamã.

MARX, K. (1980) Existência e consciência. In: lanni, O. (Org.). Sociologia. São Paulo: Câmara Brasileira do Livro. 
MICHAELIS, L. (2000) Ethics of consumption. Ethics \& Society. Available: http://spin.medic.ukm.my/Contents/ZZZT3133/ZZZT3133/CModule/Lesson13/131534 4428_EthicsofConsumption.pdf Access: 22/11/ 2011.

MONT, O. (2004) Institutionalisation of sustainable consumption patterns based on shared use, Ecological Economics, v. 50, p.135-153.

OCDE. Organization for Economic Co-operation and Development. (2006) OCDE. Available: http://www.oecd.org/ Access: 25/04/2012.

ONARAN, Ö. (2010) The crisis of capitalism in Europe, West and East. Monthly Review. Available: http://monthlyreview.org/author/ozlemonaran Access: 21/05/2012.

ORDANINI, A.; MICELI, L.; PIZZETTI, M.; PARASURAMAN, A. (2011). Crowdfunding: transforming customers into investors through innovative service platforms, Journal of Service Management, v. 22; n. 4, p. 443-470.

PROTHERO, A.; FITCHETT, J. A. (2000) Greening Capitalism: opportunities for a green commodity. Journal of Macromarketing, v. 20, n. 1, p. 46-55.

SEYFANG, G. (2006) Ecological citizenship and sustainable consumption: examining local organic food networks, Journal of Rural Studies, v. 22, n. 4, p. 383-395.

SMITH, N. (2007) Nature as accumulation strategy, Socialist Register, v.43.

SPAARGAREN, G.; OOSTERVEER, P. (2010) Citizen-Consumers as Agents of Change in Globalizing Modernity: The Case of Sustainable Consumption, Sustainability, v. 2 , n. 7, p. 1887-1908

SWEET, S.; MOEN, P. (2004) Coworking as a career strategy: Implications for the work and family lives of university employees, Innovative Higher Education, v. 28, n. 4 , p. 255-272.

THORPE, B. (2009) Clean Production Strategies: What is Clean Production? Available: http://www.cleanproduction.org/library/Factsheet1_Clean_Production.pdf Access: 25/11/ 2012.

UNICEF. United Nations Children's Fund. (2010) UNICEF. Available:

http://www.unicef.org/ Access: 27/11/2012.

UNDP. Creating Value for All. United Nations Development Programme. Available: http://www.undp.org/content/dam/rwanda/docs/povred/RW_rp_Creating_Value_for_A II_Doing_Business_with_the_Poor.pdf Acess: 14/04/2012.

UNIDO. United Nations Industrial Development Organization. (2002) Manual on the Development of Cleaner Production Policies - Approaches and Instruments. UNIDO CP Programme. Available: http://www.unido.org/fileadmin/import/9750_0256406e.pdf Access: 25/11/ 2012.

VANDEPITTE, M. (2011) Crisis del capitalismo. Rebelión. Available: http://www.rebelion.org/noticia.php?id=121086 Access: 23/05/2012.

VIANNA, M.; VIANNA, Y.; ADLER, I. K.; LUCENA, B.; RUSSO, B. (2012) Design Thinking: Inovação em Negócios. Rio de Janeiro: MJV Press.

WORLD BANK. (2012) World Development Report. Available: http://wdronline.worldbank.org/ Access: 28/04/2012.

WCED. World Commission on Environment and Development. (1987) Our Common Future, Oxford University Press, Oxford. 
INDEPENDENT JOURNAL OF MANAGEMENT \& PRODUCTION (IJM\&P)

http://www.ijmp.jor.br

v. 5, n. 1, October - January 2014.

ISSN: 2236-269X

DOI: 10.14807/ijmp.v5i1.117

WHO. World Health Organization. (2010) Relatório da Organização Mundial da

Saúde. Available: http://www.who.int/en/ Access: 28/04/ 2012.

YUNUS, M. (2010) Building Social Business: The New Kind of Capitalism that

Serves Humanities Most Pressing Needs. New York: Public Affairs. 